\title{
East or West
}

\section{Maintaining an Orthodox Collection inside a Lutheran-oriented Theological Library}

By Jussi Hyvärinen, University of Eastern Finland Library

ABSTRACT The School of Theology in the University of Eastern Finland consists of two study programs: Western Theology and Orthodox Theology. Its predecessor was the Faculty of Theology in the University of Joensuu (2002-2009). Before the establishment of the faculty, the university provided education in theology from the year 1988.

The development of the theological collection of the university library is intertwined with the history of the School of Theology. When the education of Orthodox priests in Finland was transferred from Kuopio Orthodox Seminary to the University of Joensuu in 1988, the Seminary Library collection was also merged into the university library. Therefore, the theological collection contained predominantly Orthodox material until the year 1997, when the university started to provide education also in Western theology. Since that time, the development of the theological collection has implied maintaining the balance between Western and Orthodox material.

I will describe the challenges of maintaining and evaluating the collection of Orthodox theology in our library. Since the classification system we have used does not distinguish between Western and Orthodox theology, we have invented a special UEF code used in cataloging. This enables distinction between Western and Orthodox material when I evaluate our collection.

\section{Eastern Orthodox Church and the Education of Orthodox Theology in Finland}

There are two churches that hold a special position in the law of Finland: the Evangelical Lutheran Church of Finland and the Finnish Orthodox Church. The Lutheran Church comprises 
a majority of 3.9 million members ( $71 \%$ of the population), while the Orthodox Church is a minority of $1.1 \%$ with its 60,000 members. ${ }^{1}$

The Finnish Orthodox Church was a part of the Russian Orthodox Church until the year 1917, when Finland achieved national independence from Russia. Since the year 1923, the Finnish Orthodox church has been an autocephalous archdiocese of the Ecumenical Patriarchate of Constantinople. The church has three dioceses and two monasteries. Along with the Lutheran Church, the Finnish Orthodox Church has the status of a state church, the position of which is regulated by a specific law of the Orthodox Church. ${ }^{2}$ Although the members of the church comprise only a small minority of the Finnish population, it has carried remarkable cultural significance, particularly in eastern Finland. The orthodox monasteries of New Valaam and Lintula in Heinävesi (North Karelia), in particular, are famous tourist attractions and places of pilgrimage.

In Finland, three universities offer degree-level education in theology: the University of Helsinki, Åbo Akademi in Turku, and the University of Eastern Finland (UEF) in Joensuu and Kuopio. The School of Theology at UEF is located at the Joensuu campus and consists of two study programs: Western theology and Orthodox theology. Even though the majority of the students study Western theology, UEF is the university where the priests and church musicians of the Finnish Orthodox Church have their education. ${ }^{3}$ It is also the only university in Nordic countries with degree-level education and research in Orthodox theology. Moreover, the Ministry of Education and Culture has defined the education of Orthodox theologians as one of the national special tasks of the University of Eastern Finland. ${ }^{4}$

The history of the education of Orthodox priests in Finland began in the year 1918, when the Finnish Government issued a decree on "the Greek Catholic Church in Finland." In the same year, the Finnish Orthodox Priest Seminary began its work in Sortavala, Ladoga Karelia. After World War II, the seminary was evacuated from Sortavala to Kuopio, where it worked for four decades until the Department of Orthodox Theology was established in the University of Joensuu in $1988 .{ }^{5}$ In 2002 , when the 
university started degree-level education also in Western theology, the Department of Orthodox Theology became a part of the newly-formed Faculty of Theology. When the Universities of Kuopio and Joensuu united and formed the University of Eastern Finland, the School of Theology became a part of the Philosophical Faculty of the new university. ${ }^{6}$

In 2018, there were 470 graduate students and 73 postgraduate students in the School of Theology. The annual intake into the program of Western theology is 59 students, while the program of Orthodox theology has the intake of 19 students a year. In other words, one-fourth of the beginners are students of Orthodox theology.

Although the students of Western and Orthodox theology study in separate programs, they have partly common studies: three academic subjects-Biblical Studies, Comparative Religion, and Religious Education-have not been divided into Western and Eastern alternatives. However, there are three subjects in the program of Western theology which have their Orthodox equivalents: Church History (Orthodox Church History), Systematic Theology (Systematic Theology and Patristics), and Practical Theology (Orthodox Practical Theology). In addition to these, the program of Orthodox theology provides studies of Orthodox Church Music, which means that both the priests and the church musicians of the Finnish Orthodox Church have completed a master's degree in theology. ${ }^{7}$

\section{The Collection of Orthodox Theology in the University of Eastern Finland Library}

The University of Eastern Finland Library provides services for four faculties: the Philosophical Faculty (which contains the School of Theology), the Faculty of Science and Forestry, the Faculty of Health Sciences, and the Faculty of Social Sciences and Business Studies.

The theological collection of the university is mainly located in the Joensuu Campus Library. There are no separate collections of Western and Orthodox theology, and the shelf marks of the books are not arranged by the academic subjects studied in the School of Theology. Since the library was established in 1969, all shelf marks in the library have followed the Finnish version 
of UDC, which was created on the basis of the old version of the Universal Decimal Classification. Therefore, the shelf mark 23 stands for systematic theology, 25 is for pastoral theology, etc.

The development of the theological collection of the university library is intertwined with the history of the School of Theology. In the first phase (1969-1988), the theological collection of the library was very small; in 1986, there were only two thousand books and twenty periodicals, and the collection served mainly the needs of the students of education. ${ }^{8}$ Because of the small acquisitions budget, the donations received by institutions and private persons played a significant role in the accession of the library collection.

The year 1988 was a turning point in the history of the theological collection of the library. When the education of Orthodox priests in Finland was transferred from Kuopio to the University of Joensuu, the Orthodox Seminary Collection was received as a donation from the Orthodox Seminary of Finland. The donors had expressed a wish to establish a separate library for the Department of Orthodox Theology, but it was not fulfilled because of the lack of facilities. ${ }^{9}$

The Orthodox Seminary Collection contains literature on theology and other fields, mostly in the Finnish language. The theological part has been incorporated into the library's collections and cataloged into the library's UEF Finna database. A part of the collection remains uncataloged in storage at the Joensuu Campus Library. The uncataloged part contains, for instance, valuable collections of Orthodox hymns and Church Slavonic liturgies. ${ }^{10}$

In 1993, the University of Joensuu received another remarkable collection of Orthodox literature from the Finnish Orthodox Church's Public Library. This collection was not a donation, but the Church sent it to the university library for preservation and usage for academic purposes. It includes Orthodox theological literature and general literature. The older material is written mostly in Church Slavonic and Russian, while the newer material is in Finnish, English, and other languages. For the main part, the collection has been cataloged into the UEF Finna database. ${ }^{11}$

Another significant donation was the Archbishop Johannes Collection, which was donated to the University of Joensuu Library in 2000 by the Archbishop Johannes (1923-2010) of the 
Finnish Orthodox Church. It contains mainly theological literature, which has been mostly cataloged into the UEF Finna database. ${ }^{12}$ The uncataloged part contains a remarkable collection of Orthodox theology written in Greek.

In the years 1988-1997, the theological collection of the university library contained predominantly Orthodox material; for example, the library had achieved a representative collection of patristics, liturgics, and Orthodox church music. When the university started to provide education also in Western theology in 1997, funding for the acquisition of theological material increased considerably and focused specifically on Western theology which had the greatest deficiencies. In this process, the particularly significant fields of study were pastoral psychology, Nordic (Lutheran) Church history, and the theology of Reformation.

When the university started to award degrees also in Western theology, and the Faculty of Theology was established in 2002, the students of Orthodox theology became a minority in the faculty. Since that time, the development of the theological collection has implied maintaining the balance between Western and Orthodox material. A constant question is how to take into account the wishes of both programs with regard to both receiving donations and making purchases of new material. The acquisitions are also dependent on the staff's own activity: as most of the acquisition proposals are being implemented, a professor who is actively involved in the library can influence the coverage of the collection in his/her own field of study.

In the twenty-first century, the focus of acquisitions in most disciplines has shifted to ebooks and electronic journals. Although the electronic collection of the library is gradually replacing the print collection, this does not apply to disciplines like humanities and theology, the acquisition budgets of which are still being spent for the most part on print monographs.

\section{My Role as a Subject Librarian: an Orthodox Collection Main- tained by a Lutheran}

As a multidisciplinary library of a multidisciplinary university, UEF Library has considered it necessary to recruit subject librarians who have specialized in the disciplines studied and taught in the university. The library became aware of the need 
for an expert of theology especially in 2002, when the Faculty of Theology was established. When I started to work in the UEF Library in 2007, I was the first employee with a degree in theology. I was given responsibility for the theological collection, which means one hall in the Joensuu Campus Library where the print materials of history, theology, and culture studies are located.

The Training and Information Services in UEF Library are organized on the basis of the idea of subject librarianship. A discipline-specific information specialist is responsible for the print collections and digital resources of his or her own discipline from acquisition and subject indexing to evaluation and weeding. He/she is also responsible for discipline-specific reference work and information literacy teaching in all phases of studies from the first year to the doctoral thesis. In collection work, my most important tasks are the acquisition and subject indexing of theological material. Although I am responsible for the theological collection of the library, my acquisition requests are only recommendations and consulting; the final decisions are made by the collection department of the library, which is also responsible for the budget.

My identity as a subject librarian has developed step by step. In the past few years, there has been discussion in the UEF Library about the idea of embedded librarianship, which should replace the former library-centered schemes of things; a subject librarian should be like a "mobile department library." ${ }^{13}$ Gradually, I have become conscious of my role as an "interpreter" between the library and the School of Theology; as I speak both languages, I can also help them in communication and understanding each other's needs and views. However, a special challenge in my work is the fact that different subject areas-the Orthodox and the Western-require more or less different types of expertise.

As I am a member of the Lutheran Church and have completed my degree in Western theology, I am, in principle, a representative of the Lutheran majority. The collections and research themes of Lutheran theology represent for me "the familiar," to which I don't need to pay special attention. In contrast, Orthodox theology represents "the other" that opens 
up more slowly. Therefore, especially in the beginning, my work on the collections was slowed down by the difficulty of understanding Orthodox thinking, and I had to explore subject matters that where more or less unfamiliar to me: the writings of Syrian Church Fathers, the theology of icons, the sacraments of Holy Orders and Unction, neums in Medieval Russian church music, and the significance of the saints and the God-bearer in Orthodox faith. Fortunately, I had studied Russian before; a significant part of the Orthodox collection consists of books written in Russian or other Slavic languages, especially Church Slavonic.

As the majority of the acquisition requests comes from the department of Western theology, it is necessary to keep the needs of Orthodox theology in mind. This requires continuous collaboration with the staff of the School of Theology and keeping up to date regarding the research that is done both in the Western and the Orthodox programs of the school.

As a subject librarian, I must often ask myself if I should maintain a collection that contains everything about Orthodox theology or a collection that is actively used. As the facilities are limited, why preserve books which nobody seems to read? When the accession to the collection of theology is about 500 new books a year, it is, of course, necessary to weed older material. In some disciplines, this can be easier, but the problem of theology is that the literature never becomes outdated. The collections are weeded mainly on the basis of the circulation statistics: if a book has been borrowed only once or twice after the year 2000, it belongs among the first books to weed. Because of the minority status of Orthodox theology, I am very careful in weeding the Orthodox collection, although the weeding process does not mean that a book totally disappears from the Finnish library system: it is sent to the National Repository Library which receives, stores, and offers material for the use of other libraries in Finland. ${ }^{14}$

\section{The UEF Collection Classification Code as a Tool for Evalua- tion, 2008-2017}

A constant problem concerning the evaluation of the theological collection in the Joensuu Campus Library is the difficulty of separating the Western and Orthodox materials from each other. 
This problem is related to the question of whether all branches of Western and Orthodox theology are equally taken into account in the collection politics. As stated before, the theological collection in our library is not divided into Western and Orthodox sections, and the UDC-based classification system we have used makes no distinction between Western and Orthodox theology. Also, the academic subjects taught and studied in the School of Theology have no direct equivalents in the former classification system and shelf marks used in our library.

The UEF collection classification code was invented in 2007 by a working group set up by the University of Joensuu Library. The purpose of the UEF code was to serve as a tool of evaluation of the discipline-specific collections in the library. In this system, every new print title acquired in the library was given a classification code, which followed the disciplines taught and studied in the university. This made it possible to track the increase in titles, the number of loans, and the total number of titles according to the subject areas..$^{15}$ As regards the theological collection, the UEF classification codes were created according to academic subjects taught in the School of Theology. This decision not only made it possible to make a distinction between Western and Orthodox material, but it also allowed me analyze every academic subject separately when I evaluated our collection.

The UEF code came into use in the University of Joensuu Library in 2008 and, after the merger of the Universities of Joensuu and Kuopio, in the University of Eastern Finland Library in 2010. It was not used retrospectively because the main purpose of the code was to evaluate acquisition and accessions. So, the UEF code was added only into the records of newly acquired titles. At the same time, the library abandoned UDK codes (the Finnish version of UDC) as a tool of classification. ${ }^{16}$ In 2011, the Library of Congress accepted the UEF code to be used in the 084 MARC field, and the code was added into the list of Source Codes, Vocabularies, and Rules. ${ }^{17}$

In the UEF code table, the subject areas of theology were marked with eleven codes, which were equivalent to the academic subjects taught at the School of Theology. The following chart contains the list of UEF codes of theology, the corresponding 
subject areas, and the number of print theological titles tagged with the UEF code by the end of the year 2017.

\begin{tabular}{llc} 
UEF CODE & \multicolumn{1}{c}{ SUBJECT AREA } & $\begin{array}{c}\text { NUMBER OF PRINT BOOKS } \\
\text { ACQUIRED 2008-2017 }\end{array}$ \\
\hline UEF:20 & Theology. General & 221 \\
\hline UEF:20eks & Biblical Studies & 1,150 \\
\hline UEF:20his & Church History & 577 \\
\hline UEF:20hisor & Orthodox Church History & 306 \\
\hline UEF:20kas & Religious Education & 55 \\
\hline UEF:20kay & $\begin{array}{l}\text { Practical Theology } \\
\text { (Western) }\end{array}$ & 675 \\
\hline UEF:20kayor & $\begin{array}{l}\text { Practical Theology } \\
\text { (Orthodox) }\end{array}$ & 238 \\
\hline UEF:20musor & Orthodox Church Music & 117 \\
\hline UEF:20sys & $\begin{array}{l}\text { Systematic Theology } \\
\text { (Western) }\end{array}$ & 670 \\
\hline UEF:20sysor & $\begin{array}{l}\text { Systematic Theology and } \\
\text { Patristics (Orthodox) }\end{array}$ & 253 \\
\hline UEF:20usk & Comparative Religion & 989 \\
\hline
\end{tabular}

According to the chart, there were in all 5,251 titles acquired into the collection of theology in the years 2008-2017. As the collection contains approximately 25,000 print books, this means that one-fifth of them have been marked with the UEF code. The chart also shows that 914 items fall under the category of Orthodox theology, which is only $17.4 \%$ of the total. However, it should be noted that over $40 \%$ of the books can be considered as "neutral," neither especially "Western" nor "Orthodox."

When attention is paid to the UEF codes of Orthodox theology (20hisor, 20kayor, 20sysor, and 20musor), and they are compared with the corresponding codes of Western theology (20his, 20kay, and 20sys), it can be seen that the number of Western titles is about two or three times greater than that of Orthodox titles. On the other hand, the chart shows that all academic subjects in the School of Theology, both Western and Orthodox, have been taken into account in the acquisition policy of the library. The annual data on additions to the theological collection 
have also determined which subject areas should be borne in mind more than before. For instance, if some year the number of acquired books about Orthodox church music seemed small, I had to consider the reason for it and take it into account when making acquisition requests.

During the years when UEF code was in use as a tool of evaluation, one general trend was visible above all: a continuous decrease in the number of acquired print books. The Faculty of Science and Forestry and the Faculty of Health Sciences, in particular, represent the branches of sciences in which research is practically no longer published as print monographs. Moreover, the acquisition policy of the library prefers ebooks; if a book is available as an electronic version, the library will purchase it instead of the print version. As the chart below shows, the total increase in print books decreased from 7,551 titles in 2011 to 4,188 titles in 2016:18

\begin{tabular}{|c|c|c|c|c|c|c|}
\hline YEAR & 2011 & 2012 & 2013 & 2014 & 2015 & 2016 \\
\hline $\begin{array}{l}\text { Total increase of } \\
\text { titles }\end{array}$ & 7,551 & 7,102 & 7,065 & 5,407 & 4,678 & 4,188 \\
\hline $\begin{array}{l}\text { Philosophical } \\
\text { Faculty }\end{array}$ & 2,832 & 2,677 & 2,920 & 2,166 & 1,998 & 1,734 \\
\hline $\begin{array}{l}\text { School of Theology } \\
\text { (part of the Phil.) }\end{array}$ & $\begin{array}{r}546 \\
\text { (7\% of } \\
\text { total } \\
\text { increase) }\end{array}$ & $\begin{array}{r}501 \\
(7 \%)\end{array}$ & $\begin{array}{r}680 \\
(9.6 \%)\end{array}$ & $\begin{array}{r}500 \\
(9.2 \%)\end{array}$ & $\begin{array}{r}448 \\
(9.6 \%)\end{array}$ & $\begin{array}{r}469 \\
(11.2 \%)\end{array}$ \\
\hline
\end{tabular}

However, as can be seen, the number of titles acquired in the field of theology remained almost the same or decreased only slightly during the given six years. As a result, theological books as a proportion of the total increase in titles grew from $7 \%$ in 2011 to $11.2 \%$ in 2016 . This can be seen either as evidence of the conservativeness of theologians who prefer printed monographs or as a result of the fact that, in many cases, an electronic version of a print book is just not available. In the collection of theology in the UEF Library, this problem applies especially to books published in German or Russian.

The introduction of the UEF code also made it possible to explore the circulation of books in relation to their UEF codes. 
The following chart shows how the loans of theological books were related to the number of the titles in 2013 ,

\begin{tabular}{lrrrrrrr}
$\begin{array}{l}\text { UEF } \\
\text { CODE }\end{array}$ & 20hisor & 20kayor & 20sysor & 20musor & 20his & 20kay & 20sys \\
\hline $\begin{array}{l}\text { Number of } \\
\text { titles 2013 }\end{array}$ & 208 & 160 & 137 & 50 & 392 & 431 & 418 \\
\hline Loans & 60 & 31 & 35 & 20 & 159 & 191 & 134 \\
2013 & 0.29 & 0.29 & 0.26 & 0.20 & 0.41 & 0.44 & 0.32 \\
\hline $\begin{array}{l}\text { Loans/titles } \\
2013\end{array}$ & & & & & & & \\
\hline
\end{tabular}

According to these figures, even the newly acquired theological titles were not among the most borrowed research books in the UEF Library. The most borrowed subjects by the UEF code in 2013 were Special Education (UEF:37ERI; 1.75 loans/title) and Psychology (UEF:1599; 0.96 loans/title). Furthermore, the circulation of Orthodox theology books was remarkably lower than that of Western books: the average loans per title of Orthodox theology was 0.26 , while the average of Western theology books was 0.39 . This can be explained by the smaller number of students and researchers of Orthodox theology. However, I did not decide to reduce the acquisitions of Orthodox theology in favor of Western theology, as I remembered the duty of UEF as a maintainer of Orthodox research and studies in Finland.

As the reader has noticed, I have described the use of the UEF collection classification code in past tense; the UEF code is not in use any more because the library decided to abandon it by the end of 2017. The reason for this was the fact that it was no longer sensible to concentrate on print collections in the evaluation process as an ever growing majority of new books are purchased in electronic form and often as large collections provided by the publishers. In my opinion, however, the UEF code would still have been a usable tool for the evaluation of the theological collection because of the dominance of print books in theology as compared to other disciplines in the university.

\section{A Glance at Master's and Doctoral Theses}

One way to examine if the collection of theology in our library meets the needs of students is by comparing the contents of the 
collection with the subjects the students are studying. The bibliographies of master's and doctoral theses can also give us information about the coverage of our collection.

In the years 2010-2018, there were a total of forty-four master's theses and five doctoral theses on Orthodox theology written at the University of Eastern Finland. These numbers do not include theses written by Orthodox students on Comparative Religion, Biblical Studies, and Religious Education, as these subjects are common with the students of Western theology.

The academic subjects of the master's theses on Orthodox theology were divided so that half of them (twenty-two theses) were written on practical theology. The second most popular subject was Orthodox church music (eleven theses; 25\%), while the remaining $25 \%$ were divided into systematic theology and Patristics, and Orthodox church history. When these numbers are compared with the corresponding UEF codes and titles acquired in 2008-2017, their order is opposite: the first in order was Orthodox church history (20hisor; 306 titles), the second was systematic theology and Patristics (20sysor; 253 titles), the third was practical theology (20kayor; 238 titles), and the last was Orthodox church music (20musor; 117 titles). So, I have concluded that I must pay special attention to the collection of Orthodox music when making acquisition requests.

In the years 2012-2018, there were four doctoral theses on Orthodox theology published in the UEF Electronic Publications series. There was one thesis on systematic theology ${ }^{19}$, one on Church history ${ }^{20}$, one on Church music ${ }^{21}$, and one on practical theology. ${ }^{22}$ Because I was interested in the question of how many sources in their bibliographies are available in our library collection, I made a search in the UEF Finna database. Below I explain my results.

The result of my search was that almost all (95\%) of the sources in the bibliography of Timo Hirvonen's thesis are available in the UEF Library. Also, most sources (81.5\%) used by Eeva Raunistola-Juutinen are available in the library or on the web. Half (52.5\%) of the sources used by Irina Karvonen could be found in UEF Finna or on the web, while only $31.8 \%$ of the sources used by Maria Takala-Roszczenko were available in the same way. However, it does not necessarily mean that we have 


\begin{tabular}{|c|c|c|c|c|c|c|}
\hline $\begin{array}{l}\text { PRACTICAL } \\
\text { THEOLOGY }\end{array}$ & YEAR & $\begin{array}{l}\text { ACADEMIC } \\
\text { SUBJECT }\end{array}$ & $\begin{array}{l}\text { NUMBER } \\
\text { OF } \\
\text { SOURCES }\end{array}$ & $\begin{array}{l}\text { SOURCES } \\
\text { FOUND } \\
\text { IN UEF } \\
\text { FINNA }\end{array}$ & $\begin{array}{c}\text { SOURCES } \\
\text { NOT } \\
\text { FOUND IN } \\
\text { UEF FINNA } \\
\text { OR ON THE } \\
\text { WEB }\end{array}$ & $\begin{array}{l}\text { OPEN } \\
\text { SOURCES } \\
\text { ON THE } \\
\text { WEB }\end{array}$ \\
\hline $\begin{array}{l}\text { Raunistola- } \\
\text { Juutinen }\end{array}$ & 2012 & $\begin{array}{l}\text { Systematic } \\
\text { theology }\end{array}$ & 353 & 240 & 65 & 48 \\
\hline Karvonen & 2013 & $\begin{array}{l}\text { Church } \\
\text { history }\end{array}$ & 171 & 65 & 81 & 25 \\
\hline $\begin{array}{l}\text { Takala- } \\
\text { Roszczenko }\end{array}$ & 2013 & $\begin{array}{l}\text { Church } \\
\text { music }\end{array}$ & 264 & 62 & 180 & 22 \\
\hline Hirvonen & 2017 & $\begin{array}{l}\text { Practical } \\
\text { theology }\end{array}$ & 80 & 76 & 4 & 0 \\
\hline
\end{tabular}

a notably poor collection of Orthodox church music, for TakalaRoszczenko has used in her thesis mainly Polish and Ukrainian sources, while most research at UEF has concentrated on Finnish and Russian church music.

\section{Conclusion}

The preceding chapters were a kind of retrospective; the UEF code was designed for evaluating the collection of print books, but it was finally discontinued because of the fast growing number of ebooks and electronic journals in the collections. After the year 2010, the focus of the acquisition of books has radically moved from print books to ebooks. This change also concerns the collection of theology: a search in UEF Finna database with the keyword "patristics" gives as a result 175 printed books and 141 ebooks, and the result list of a search with the keyword "orthodoxy" contains 186 print books and 431 ebooks.

The print collection of theology was created and grown especially in the 1980s and 1990s. Print publications, especially monographs, still make up a significant portion of the material acquired for the collection of theology. So, this phase does not belong to the past.

In the 2000s, more and more theological books and journals have been acquired in digital form. Reference and full text databases have also become an important part of the collection. The university has purchased or subscribed access to ATLA Religion 
Database, Proquest's Luther's Works in WWW and Acta Sanctorum, Brill's Religion Past and Present, Textual History of the Bible and Gregorii Nysseni Opera Online, and de Gruyter's Encyclopedia of Bible and its Reception Online. The most recently purchased database was Thesaurus Linguae Graecae. In the acquisition of ebooks, theological material is mostly acquired automatically within EBSCO and Ebook Central subscriptions. An electronic library of the databases of theology can be built this way, but it is not easy to estimate how their content meets the special needs of the Orthodox theologians. Another problem is that in some cases, expensive databases have been acquired for a small number of users.

When considering the future, it is important ot ask what is the role of academic libraries when print and licensed electronic collections are replaced by open access digital archives of digitized or born-digital books and articles. As the main task of the print library was warehousing, and the digital library has a role as e-journal and ebook supplier, now libraries have taken the role of an e-resource counselor with new tasks like digitizing and publishing services..$^{23} \mathrm{UEF}$ is committed to open access policy and has started publishing research in open access form. The university's own publications and serials are all published on the open web, and parallel publishing of the articles of the researchers at UEF has been started as a project of the library.

Some departments have also planned to digitize their own serials and publish them on the web retrospectively. There have been discussions between the library and the School of Theology about digitizing their old publications like the journal Ortodoksia, the latest volumes of which have been published open access. There have also been discussions with the New Valaam monastery about digitizing their old, precious Russian and Church Slavonic books; this project would have great cultural significance. With these steps, we move towards the dream of all students and researchers, when all old publications have been digitized and all new research is published open access all over the world.

In this connection, I must ask myself the question, "What will my role as a theological librarian be in the future?” Information retrieval teaching, counselling, and information services will 
be my tasks also in the changing online environment. The most important thing is to help everybody to find the material they need, regardless of whether it is a part of the library collection or it is on the open web. ${ }^{24}$

\section{NOTES}

1 “Population," Statistics Finland, http://www.stat.fi/tup/suoluk/ suoluk_vaesto_en.html.

2 “Orthodox Church of Finland," Britannica Academic, Encyclopædia Britannica, 7 Apr. 2009. Academic-eb-com.ezproxy. uef.fi:2443/levels/collegiate/article/Orthodox-Church-ofFinland/57482.

3 Matti Kotiranta, About the School of Theology, http://www.uef.fi/en/ web/teol/tietoa-osastosta.

4 "A Pact Between the Ministry of Education and Culture and the University of Eastern Finland [in Finnish]," http://minedu.fi/ documents/1410845/3992810/It\%C3\%A4-Suomen+yliopisto+s opimus+2017-2020.

5 Petri Piiroinen, Suomen ortodoksinen pappisseminaari 1918-1978 (Joensuu: Suomen ortodoksisen pappisseminaarin oppilasyhdistys, 1978), 25-33.

6 Kotiranta, About the School of Theology.

7 “Orthodox Theology,” http://www.uef.fi/en/web/teol/ortodoksinen-teologia.

8 "A Record of a Negotiation Between the Joensuu University Library and the Library of the New Valaam Monastery," 30 May 1986, unpublished document from the archives of the UEF Library.

9 Jenni Mikkonen, "An Interview of the Librarian Tapani Toivanen,” 23 May 2005, unpublished document from the archives of the UEF Library.

10 “Special collections," UEF Library homepage, http://www.uef.fi/ web/kirjasto/kokoelmat/erikoiskokoelmat.

11 Ibid.

12 Ibid.

13 See Kathy Dreves and Nadine Hoffman, "Academic Embedded Librarianship: An Introduction," Public Services Quarterly 6 (2010): 75-82. 
14 “The National Repository Library: Aims and Function," http:// www.varastokirjasto.fi/aims-and-function/.

15 Kaarina Meriläinen, Riitta Porkka, and Laura Parikka, ”UEFaihealuekoodisto evaluoinnin välineenä Itä-Suomen yliopiston kirjastossa," Signum (2012).

16 Ibid.

17 “Library of Congress: Technical Notice” (February 09, 2011), https://www.loc.gov/marc/relators/tn110209src.html.

18 Data collected and analyzed by Mikko Meriläinen (UEF Library).

19 Eeva Raunistola-Juutinen, Äiti ja nunna: Kirkkojen Maailmanneuvoston naisten vuosikymmenen ortodoksiset naiskuvat (Joensuu: University of Eastern Finland, 2012), http://urn.fi/ URN:ISBN:978-952-61-0972-5.

20 Irina Karvonen, Pyhän Aleksanteri Syväriläisen koulukunta: 1500luvun luostarihistoriaa vai 1800-luvun venäläiskansallista tulkintaa? (Joensuu: University of Eastern Finland, 2013), http:// epublications.uef.ri/pub/urn_isbn_978-952-61-1132-2/urn isbn_978-952-61-1132-2.pdf.

21 Maria Takala-Roszczenko, The 'Latin' Within the 'Greek': The Feast of the Holy Eucharist in the Context of Ruthenian Eastern Rite Liturgical Evolution in the 16th-18th Centuries (Joensuu: University of Eastern Finland, 2013), http://urn.fi/URN:ISBN:978-952-61-1302-9.

22 Timo Hirvonen, Suomenkielinen ennenpyhitettyjen lahjain liturgia - kirkkopolitiikan pyörteistä liturgiseksi liikehdinnäksi (Joensuu: University of Eastern Finland, 2017), http://epublications.uef. fi/pub/urn_isbn_978-952-61-2652-4/urn_isbn_978-952-612652-4.pdf.

23 See Jarmo Saarti, “Collection Policies for the Post-Digital Era of Academic Publishing-Future Scenarios For the Academic Libraries," in Repositories for Print: Strategies for Access, Preservation and Democracy, ed. Pentti Vattulainen and Steve O'Connor (Berlin; Boston: de Gruyter Saur, 2018), 110-17.

24 See Janine Schmidt, “Developing a Library Collection Today: Revisiting 'Collection Evaluation, the Conspectus and Chimeras in Library Cooperation,”' Australian Academic \& Research Libraries 47, no. 4 (2016): 190-95, https://www.tandfonline.com/doi/full $\underline{\text { /10.1080/00048623.2016.1250598. }}$ 